ORIGINAL ARTICLE

\title{
Salivary duct carcinoma: immunohistochemical profile of an aggressive salivary gland tumour
}

\author{
A Etges, D S Pinto, Jr, L P Kowalski, F A Soares, V C Araújo
}

See end of article for authors' affiliations .....................

Correspondence to: $\operatorname{Dr} \vee C$ de Araújo, Faculdade de Odontologia da Universidade de São Paulo/USP, São Paulo, Avenida Prof. Lineu de Azevedo Prestes, 2227 Cidade Universitária, São Paulo, SP, Brasil, CEP: $01509-900$.

vcaraujo@usp.br

Accepted for publication 29 May 2003
Background: Salivary duct carcinoma (SDC) is considered to be a distinct malignancy of the major salivary glands, because of its highly aggressive behaviour, and the high rate of recurrence, metastasis, and disease related death.

Aims: To investigate expression of the proteins involved in the retinoblastoma (pRb) and p53 pathways, which control cell cycle progression at the G1/S checkpoint, and also expression of the c-erbB-2 oncoprotein in SDCs.

Methods: Using a streptavidin-biotin method, five cases of SDC were evaluated immunohistochemically for the presence of cyclin D1, CDK4 (cyclin dependent kinase 4), p16 (CDK2A), pRb (retinoblastoma protein), E2F-1, p53, mdm2 (murine double minute 2), bcl-2, and the c-erbB-2 oncoprotein to determine whether there was a correlation between the expression of these proteins and patient outcome.

Results: All of the cases showed deregulation of the pRb and p53 pathways. Of the five patients analysed, only the patient with longterm survival ( 10 years) was not positive for c-erbB- 2 expression.

Conclusions: c-erbB-2 overexpression was associated with a poor prognosis. Aggressive behaviour, recurrence, and metastatic potential do not appear to be related to cell cycle deregulation, but seem to be associated with the c-erbB-2 oncoprotein, which is involved in matrix degradation and proteolitic activity, in addition to increases in vessel permeability, endothelial cell growth, proliferation, migration, and differentiation. There was a correlation between c-erbB-2 oncoprotein expression and aggressive behaviour in SDCs.
$\mathrm{C}$ arcinomas of the salivary glands are rare tumours, which account for less than $1 \%$ of all head and neck malignancies. They are characterised by indolent growth and longterm survival. ${ }^{1}$ Salivary duct carcinoma (SDC) is thought to be a distinct malignancy of the major salivary glands, because of its highly aggressive behaviour, high rate of recurrence, nodal and distant metastases, and death related to the tumour. ${ }^{2-4}$

The clinical aspects and the histopathological patterns of SDCs are well described. The tumour is more frequent in elderly men, occurring predominantly in the parotid gland and occasionally in the submandibular gland..$^{35}$ Histologically, it shows a striking resemblance to breast carcinoma of the ductal type, presenting intraductal and invasive components. ${ }^{6}$

Although SDC is considered to have one of the worst short term prognoses of all salivary gland tumours, few studies have used prognostic biomarkers. The markers that have been studied include DNA content and $\mathrm{Ki}-67$, proliferating cell nuclear antigen, c-erbB-2, and p53. ${ }^{6-13}$ However, these studies came to no firm conclusions and no correlations were found with patient outcome.

\footnotetext{
"Salivary duct carcinoma is thought to be a distinct malignancy of the major salivary glands, because of its highly aggressive behaviour, high rate of recurrence, nodal and distant metastases, and death related to the tumour"
}

The aim of our study was to investigate the retinoblastoma $(\mathrm{pRb})$ and $\mathrm{p} 53$ pathways, which are involved in the control of the cell cycle at the Gl/S checkpoint, and the c-erbB-2 oncoprotein in SDC because of the highly aggressive nature of this tumour.

\section{MATERIALS AND METHODS}

Five cases of salivary duct carcinoma were retrieved from the archives of the A. C. Camargo Cancer Hospital, São Paulo, Brazil. The cases were selected on the basis of their microscopic appearance. Sections ( $3 \mu \mathrm{m}$ thick) were cut from the $10 \%$ formalin fixed, paraffin wax embedded specimens, and stained by the streptavidin-biotin method, using antibodies directed against cyclin Dl (Dako, Glostrup, Denmark), cyclin dependent kinase 4 (CDK4; Santa Cruz Biotechnology, Santa Cruz, California, USA), pl6 (Neomarkers, Freemont, California, USA), E2F-1 (Santa Cruz), retinoblastoma protein (pRb; Dako), p53 (Dako), murine double minute 2 (mdm2; Novocastra, Newcastle upon Tyne, UK), bcl-2 (Novocastra), and c-erbB-2 (Dako) (table 1). Sections were dewaxed, rehydrated in graded alcohols to distilled water, and then subjected to antigen retrieval (table 1 ). They were then incubated with $0.3 \%$ hydrogen peroxide in methanol (30 minutes) to quench endogenous peroxidase, followed by incubation in $1 \%$ bovine serum albumin in buffered solution for 60 minutes and with avidin-biotin complex to block biotin crossreaction. The sections were then incubated with primary antibody (table 1) and immunostained with streptavidin-biotin-peroxidase, followed by diaminobenzidine chromogen solution. All steps were followed by washes in buffered solution. Finally, sections were counterstained with Mayer's haematoxylin and mounted in a xylene based mountant. Negative controls were incubated in buffered solution without primary antibodies. Sections from normal salivary glands were included as internal controls.

Abbreviations: $\mathrm{CDK}$, cyclin dependent kinase; $\mathrm{mdm} 2$, murine double minute 2; pRB, retinoblastoma protein; SGT, salivary gland tumour 


\begin{tabular}{|c|c|c|c|c|c|}
\hline Antigen & Clone & Source & $\begin{array}{l}\text { Antigen } \\
\text { retrieval }\end{array}$ & Dilution & $\begin{array}{l}\text { Incubation } \\
\text { time }\end{array}$ \\
\hline $\begin{array}{l}\text { Cyclin D1 } \\
\text { CDK4 } \\
\text { pl6 } \\
\text { pRb } \\
\text { E2F-1 } \\
\text { p53 } \\
\text { mdm2 } \\
\text { c-erbB-2 } \\
\text { Bcl-2 }\end{array}$ & $\begin{array}{l}\text { DCS-6 } \\
\text { C-22 } \\
\text { Ab-4 JC2 } \\
\text { RB-1 } \\
\text { KH95 } \\
\text { DO-7 } \\
\text { 1B10 } \\
\text { Polyclonal } \\
\text { bcl-2/100/ } \\
\text { D5 }\end{array}$ & $\begin{array}{l}\text { Dako } \\
\text { Santa Cruz } \\
\text { Neomarkers } \\
\text { Dako } \\
\text { Santa Cruz } \\
\text { Dako } \\
\text { Novocastra } \\
\text { Dako } \\
\text { Novocastra }\end{array}$ & $\begin{array}{l}\text { WB } \\
- \\
\text { WB } \\
\text { WB } \\
\text { MW } \\
\text { WB } \\
\text { WB } \\
\text { WB } \\
\text { MW/ } \\
\text { EDTA }\end{array}$ & $\begin{array}{l}1 / 100 \\
1: 30 \\
1: 75 \\
1: 1000 \\
1: 1500 \\
1: 75 \\
1: 50 \\
1: 100 \\
1: 150\end{array}$ & $\begin{array}{l}60 \text { minutes } \\
60 \text { minutes } \\
60 \text { minutes } \\
45 \text { minutes } \\
45 \text { minutes } \\
40 \text { minutes } \\
40 \text { minutes } \\
40 \text { minutes } \\
40 \text { minutes }\end{array}$ \\
\hline
\end{tabular}

All immunohistochemical slides were examined for positive staining by light microscopy. We counted a minimum of 500 positive nuclei from the neoplastic cells, from five different microscopic fields at a magnification of $\times 400 ; 500$ nuclei from normal salivary gland cells were also counted as controls. The results were evaluated semiquantitatively and graded according to the following scale: cyclin D1, CDK4, and E2F-l were considered to be overexpressed when more than $20 \%$ of the nuclei showed positivity; pl6 and pRb were considered negative if all the cells showed no nuclear expression (negative nuclear expression was considered to be abnormal expression). ${ }^{14-16}$ When evaluating the expression of the c-erbB-2 protein, intense cell surface membranous staining in most cells was interpreted as positive. Diffuse cytoplasmic staining was ignored, although its importance remains uncertain. ${ }^{9}$

Table 2 provides general information about the tumours.

\section{RESULTS}

\section{Clinical findings}

The patients comprised four men and one woman, with ages ranging from 50 to 67 years (median, 58.5). All tumours were located in the parotid gland. Two patients presented regional lymph node metastases at the time of diagnosis. Four patients presented facial paralysis, one with regional lymph node metastasis. There was no evidence of metastasis in three patients. The patients were initially treated with total parotidectomy. Adjuvant treatment such as neck dissection, radiotherapy, and, in some cases, chemotherapy had no effect on the outcome. Three patients underwent radiotherapy with or without chemotherapy, and one received only

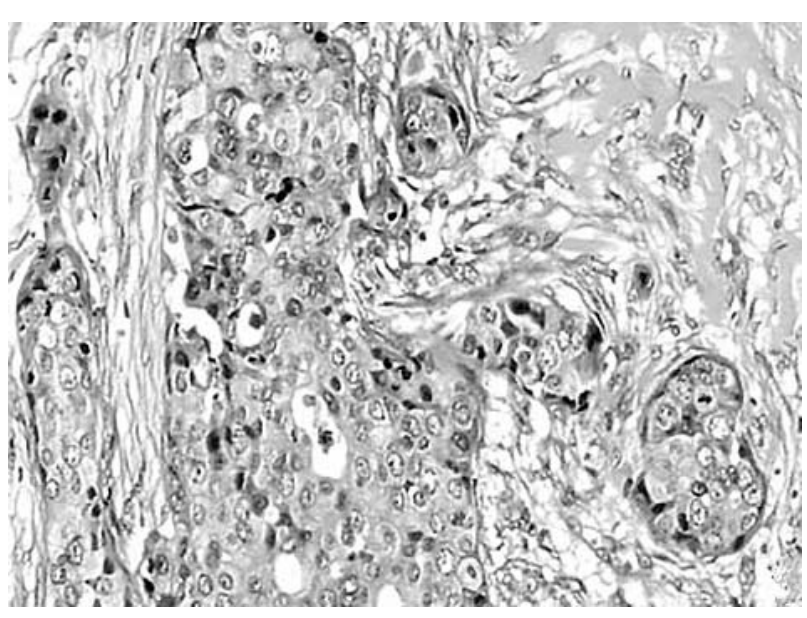

Figure 1 Solid pattern showing oval cells with a prominent nucleolus.

chemotherapy. Tumour sizes varied from $3.0 \mathrm{~cm}$ to $8.0 \mathrm{~cm}$ (median, 5.5). The outcome varied from seven months to 10 years (table 2 ).

\section{Histopathological findings}

Histologically, the tumours showed intraductal and invasive components. The intraductal component is described as a papillary or solid growth pattern, often with central necrosis. The invasive pattern is characterised by small glands and cords associated with a pronounced desmoplastic stroma (figs 1-3). This histology has a striking resemblance to breast carcinoma of the ductal type, in which intraductal growth is marked by the presence of normal myoepithelial cells confining the tumour growth within the duct. ${ }^{13}$

Normal salivary glands showed no cyclin Dl or CDK4 expression. p16 protein expression was weak in duct cells and negative in acinic cells. All normal salivary glands showed strong positivity for $\mathrm{pRb}$ and moderate expression of E2F-1.

\section{Immunohistochemical findings}

Overexpression of cyclin Dl was seen in three cases. CDK4 was overexpressed in four cases, three of which also overexpressed cyclin D1. The pl6 protein showed loss of expression in two cases, whereas pRb showed no expression in one case. In three cases, the transcription factor E2F-1 was overexpressed and in two other cases it was moderately expressed. p53 protein was overexpressed in two of the five cases by more than $50 \%$. The mdm 2 oncoprotein showed

Table 2 Clinical findings in five cases of salivary duct carcinoma

\begin{tabular}{|c|c|c|c|c|c|c|c|}
\hline Case & Age & Sex & Clinical features & $\begin{array}{l}\text { Length of } \\
\text { history }\end{array}$ & Treatment & Follow up & Outcome \\
\hline 1 & 67 & M & Parotid (7 cm, RLNM, P) & 3 years & $T P, N D, R, C$ & LR, 10 months & $\begin{array}{l}\text { Death with disease } \\
\text { after } 1 \text { year, DOD }\end{array}$ \\
\hline 2 & 60 & M & Parotid (3 cm, RLNM, P) & 2 months & $\mathrm{TP}, \mathrm{R}$ & DM, 5 months & $\begin{array}{l}\text { Death with disease } \\
\text { after } 7 \text { months, DOD }\end{array}$ \\
\hline 3 & 50 & $\mathrm{~F}$ & Parotid $(4 \times 5 \mathrm{~cm}, \mathrm{NM})$ & 4 months & TP & $C M, 7$ years & $\begin{array}{l}\text { Death with disease } \\
\text { after } 10 \text { years, DOD }\end{array}$ \\
\hline 4 & 60 & M & Parotid $(8 \mathrm{~cm}, \mathrm{NM}, \mathrm{P})$ & 45 days & $T P, N D, R$ & $L R, 1$ year & $\begin{array}{l}\text { Death with disease } \\
\text { after } 1 \text { year, } 4 \text { months, } \\
\text { DOD }\end{array}$ \\
\hline 5 & 58 & M & Parotid $(3 \times 3 \mathrm{~cm}, \mathrm{P})$ & 6 months & TP, ND, C & DM, 7 months & $\begin{array}{l}\text { Death with disease } \\
\text { after } 10 \text { months, DOD }\end{array}$ \\
\hline
\end{tabular}

Clinical staging was performed from data available in medical records.

$C$, chemotherapy; CM, cervical metastasis; DM, distant metastasis; DOD, died of disease; $F$, female; $L R$, local recurrence; $M$, male; ND, neck dissection; NM, no evidence of metastasis; $P$, facial paralysis; $R$, radiotherapy; RLNM, regional lymph node metastasis; TP, total parotidectomy. 


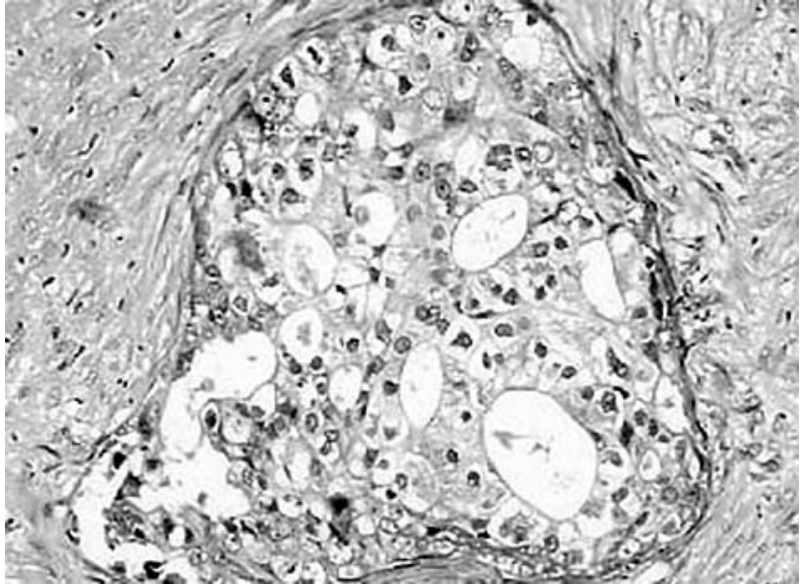

Figure 2 Cribriform pattern showing ductal structures in tumour areas.

positivity in two cases. One case in which p53 was overexpressed also showed mdm2 overexpression (table 3 ).

Four of the five cases of SDC showed positive membranous staining for c-erbB-2; in one case, c-erbB-2 expression was seen in more than $50 \%$ of the cells, and in another all of the cells were positive (fig 4). One tumour did not express c-erbB-2. None of the cases showed positivity for the Bcl-2 protein (table 3 ).

\section{DISCUSSION}

Most reports indicate that SDC is an aggressive tumour with the most dismal short term prognosis of all salivary gland tumours. ${ }^{2-4}{ }^{17}$ Thus, we investigated the relative expression of the cell cycle regulators in the pRb pathway and other biomarkers, such as p53, mdm2, c-erbB-2, and bcl-2, in an attempt to understand the biological behaviour of this tumour.

Four of the patients studied had a short follow up (up to a year), but one showed longterm survival ( 10 years). When we compared all the markers between the tumours, we found a major difference in c-erbB-2 expression. The tumour in the patient with longterm survival show a lack of c-erbB-2 expression, whereas all four patients with short survival overexpressed c-erbB-2. All cases showed Rb pathway alteration, and three cases showed abnormal expression of p53 and/or mdm2, indicating cell cycle deregulation. These alterations may be involved in the oncogenesis and progression of SDC, but the aggressive behaviour and metastasis cannot be the result of this misregulation, because matrix degradation and proteolitic activity, in addition to increases in vessel permeability, endothelial cell growth, proliferation, and migration are characteristic functions of c-erbB-2.

The overexpression of cyclin Dl seen in three of the five cases may be involved in progression and more aggressive

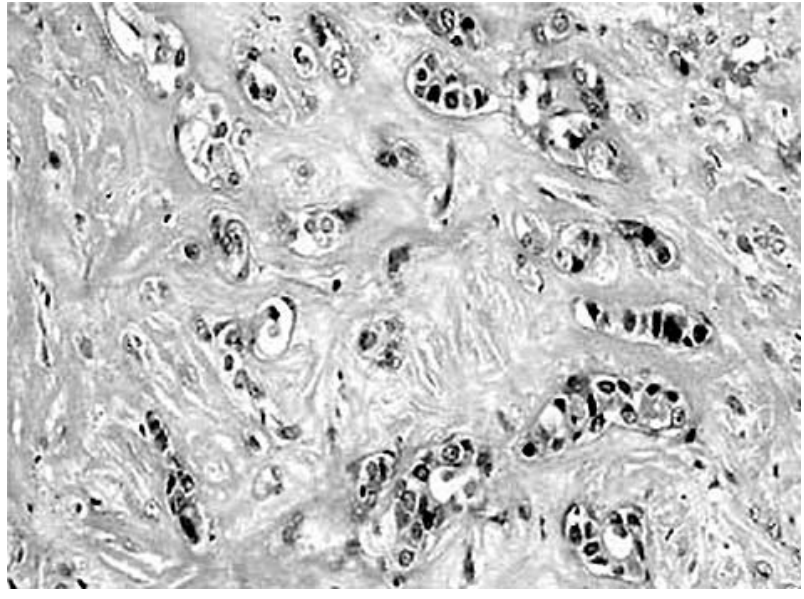

Figure 3 The invasive pattern is characterised by small glands and cords associated with a pronounced desmoplastic stroma.

tumour behaviour, as has been shown in several human cancers. ${ }^{16}{ }^{18-22}$ These observations suggest that cyclin Dl alterations might play a role in cancer aetiology, although its overexpression is not sufficient for cell transformation, with the synergistic effects of other protooncogenes being required, as pointed out by Si and Liu. ${ }^{21}$

CDK4 acts as a protooncogene when complexed with cyclin D1. ${ }^{15} 21^{23-25}$ The overexpression of CDK4, but not cyclin D1, was seen in one patient. It is possible that c-Myc could replace cyclin D, because CDK4 is a target of c-Myc. ${ }^{23} 26$ One possible cause could be its relation to APC - other studies had provided evidence of a role for $\beta$ catenin/Tcf- 4 in the control of c-Myc transcription. ${ }^{27}$

We observed loss of pl6 in two cases. p16 $6^{\text {ink } 4}$ has been implicated as a tumour suppressor gene lost from a variety of human tumours and human cell lines. ${ }^{28} 29$ Cerilli and colleagues $^{30}$ showed that pl6 inactivation is important for the development and/or progression of some SDCs through loss of heterozygosity of polymorphic genetic markers located at 9p21 and homozygous deletion. Strong pl6 expression tended to be associated with abnormal expression of cyclin Dl and CDK4. Altered expression of CDK4 is accompanied by raised concentrations of pl6, and this might be the result of compensatory upregulation of this protein to counteract CDK4 overexpression. ${ }^{15} 31$ The INK4 inhibitors of CDK4/6 participate in maintaining $\mathrm{pRb}$ in its unphosphorylated growth suppressive state. pl6 and pRb show a reciprocal pattern of alterations. ${ }^{31}$ Two cases without pl6 expression showed pRb expression, whereas one case that lost pRb expression retained pl6 expression.

The case without pRb expression showed cyclin Dl and CDK4 overexpression. Loss of pRb expression may also be explained by various mechanisms accounting for inactivation of the RB gene. Inactivation of pRb may be the result of cyclin

Table 3 Outcome and immunohistochemical protein expression in five cases of salivary duct carcinoma

\begin{tabular}{|c|c|c|c|c|c|c|c|c|c|c|}
\hline Case & Outcome & Cyclin D1 & CDK4 & p16 & $\mathrm{pRb}$ & E2F-1 & p53 & mdm2 & c-erbB-2 & Bcl-2 \\
\hline 1 & DOD, 1 year & 28.0 & 43.2 & 0.0 & 49.4 & 28.8 & 70.4 & 78.8 & 54.6 & 00 \\
\hline 2 & DOD, 7 months & 0.0 & 0.0 & 23.2 & 49.4 & 23.4 & 0.0 & 0.0 & 5.0 & 0.0 \\
\hline 3 & DOD, 10 years & 32.8 & 21.2 & 16.89 & 0.0 & 8.60 & 82.8 & 0.0 & 0.0 & 0.0 \\
\hline 4 & $\begin{array}{l}\text { DOD, } 1 \text { year/ } \\
4 \text { months }\end{array}$ & 29.8 & 20.2 & 0.0 & 51.0 & 15.6 & 0.0 & 0.0 & 12.4 & 0.0 \\
\hline 5 & DOD, 10 months & 0.0 & 62.8 & 62.0 & 31.6 & 394 & 0.0 & 76.6 & 100.0 & 0.0 \\
\hline
\end{tabular}


Dl/CDK4 overexpression, ${ }^{27}$ and pRb functions are progressively and cooperatively inactivated by multiple cyclin-CDK complexes during the $\mathrm{Gl}$ and $\mathrm{S}$ phases. ${ }^{32}$

"All of the patients who overexpressed c-erbB-2 died of their disease in less than one and a half years, but the cerbB-2 negative patient was still alive after 10 years"

All cases showed E2F-1 expression. Loss of pRb suppressor function can be associated with cyclin DI-CDK4 complex phosphorylation, thereby resulting in E2F-1 accumulation. ${ }^{32}$ One case with loss of $\mathrm{pRb}$ expression showed moderate E2F-1 expression, perhaps as a result of pRb mutation. Mutant $\mathrm{pRb}$ can act more strongly than the wild-type protein, binding to E2F-1 and inducing apoptosis. ${ }^{33}$

Two cases showed p53 overexpression, and in one case mdm2 was also overexpressed. Kubbutat et al have shown one mechanism by which p53 function is controlled by mdm2 interaction, through enhanced proteasome dependent degradation. ${ }^{34}$

Another oncoprotein studied, c-erbB-2, is very similar to the epidermal growth factor receptor. ${ }^{35}$ Based on the histological similarity between salivary and mammary glands, c-erbB-2 probably plays an important role in the development and progression of salivary gland carcinoma.

Four patients showed c-erbB-2 overexpression and death with disease within seven months, ten months, one year, and one year plus four months after diagnosis. Overexpression of c-erbB-2 oncoprotein has been associated with decreased survival in carcinoma ex pleomorphic adenoma ${ }^{36}$ and ovarian carcinoma, ${ }^{38}$ and with highly aggressive biological behaviour of breast carcinoma ${ }^{39}$ and salivary duct carcinoma. ${ }^{17}$

Patients with breast cancer with c-erbB-2 amplification have a worse prognosis than those without amplification. ${ }^{39}$ Sugano et al showed that disease free survival in patients expressing c-erbB-2 protein was significantly lower than in those not expressing c-erbB-2, and the authors suggested that SGCs with c-erbB-2 positivity are aggressive in nature and have a worse prognosis. ${ }^{37}$ Cho et al showed that disease free intervals and overall survival periods were also shorter in patients with high c-erbB-2 expression than in those negative for c-erbB-2. ${ }^{40}$

All of the patients who overexpressed c-erbB-2 died of their disease in less than one and a half years, but the cerbB- 2 negative patient was still alive after 10 years. This patient had

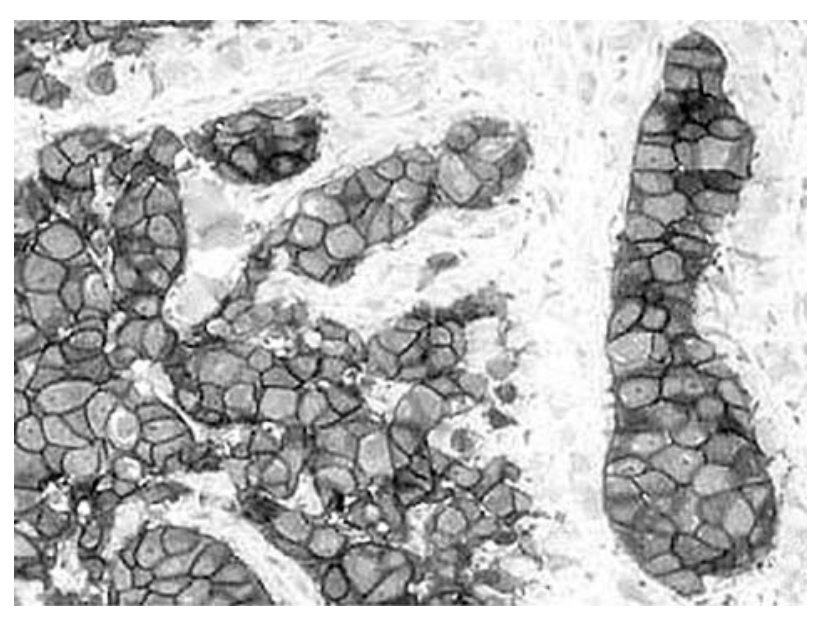

Figure 4 c-erbB-2 immunohistochemical staining of an invasive salivary duct carcinoma. The tumour cells show diffuse membranous immunoreactivity.

\section{Take home messages}

- Overexpression of c-erbB-2 was associated with a poor prognosis

- The c-erbB-2 oncoprotein is involved in matrix degradation, proteolitic activity, and increases in vessel permeability, endothelial cell growth, proliferation, migration, and differentiation

- Aggressive behaviour, recurrence, and metastatic potential do not appear to be related to cell cycle deregulation

cervical metastasis seven years after diagnosis. In mucoepidermoid carcinoma, Press et al found that c-erbB-2 immunostaining was a prognostic marker of poor clinical outcome, regardless of tumour site, size, or grade, and lymph node status. ${ }^{41}$ Overexpression of the normal c-erbB-2 gene can enhance the metastatic potential of human breast cancer cells by increasing invasion ability, which may be caused by higher metalloproteinase activity, especially type IV collagenase, through the ras-raf-mitogen activated protein kinase pathway. ${ }^{42} 43$ It was also shown that mutation activated c-erbB-2 gene can increase transformation ability, including higher cell growth and DNA synthesis rate, increased colony formation in soft agar, and tumorigenicity. A possible mechanism linking the c-erbB oncogenes with increased proteolytic activity is via activation of the Ets family of transcription factors. ${ }^{42}$ O-charoenrat and colleagues ${ }^{44}$ demonstrated c-erbB-2 expression in squamous cell carcinoma of the head and neck associated with the VEGF family, increased vessel permeability, and endothelial cell growth, proliferation, migration, and differentiation.

De Potter and Quatacker ${ }^{45}$ showed that c-erbB-2 is also found on those cell organelles involved in motility, where it presumably responds to heregulins and/or epidermal growth factor receptor ligands by heterodimerisation with other c-erbB receptors. ${ }^{42}$

Some of the molecular networks that may be induced simply by activation of members of the c-erbB family (notably in adenocarcinomas and squamous cell carcinomas), suggest that they may act as "master switches", controlling multiple aspects of the metastatic phenotype. ${ }^{42}$

Our present study showed a close correlation between c-erbB-2 oncoprotein expression and aggressive behaviour in SDCs. Our results suggest that the accumulation of oncogene and suppressor gene alterations may play an important role in SDC tumour progression, and that c-erbB-2 overexpression is a good indicator of aggressive behaviour and metastastic potential in SDC.

\section{ACKNOWLEDGMENTS}

We thank E Toddai and E dos Santos for technical assistance. Supported by FAPESP grant 99/05383-6 and CNPq grant 46111/00-0.

\footnotetext{
Authors' affiliations

A Etges, Oral Pathology, School of Dentistry, Federal University of Pelotas/UFP, Pelotas, Rio Grande do Sol, Brazil, CEP 96015

D S Pinto Jr, V C Araújo, Oral Pathology, School of Dentistry, University of São Paulo/USP, Säo Paulo, Brazil, CEP 1509-900

L P Kowalski, Head and Neck Surgery and Otorhinolaryngology Department, Cancer Hospital AC Camargo, São Paulo, Brazil, 01509010

F A Soares, Pathology Department, Cancer Hospital A. C. Camargo, São Paulo, Brazil
} 


\section{REFERENCES}

1 Spitz MR, Batsakis JG. Major salivary gland carcinoma. Arch Otolaryngol 1984;110:45-9.

2 Ruiz CC, Romero MP, Perez MM. Salivary duct carcinoma: a report of nine cases. J Oral Maxillofac Surg 1993;51:641-6.

3 Brandwein MS, Jagirdar J, Patil J, et al. Salivary gland carcinoma (cribriform salivary gland carcinoma of excretory ducts). A clinicopathologic and immunohistochemical study of 12 cases. Cancer 1990;65:2307-14.

4 Luna MA, Batsakis JG, Ordoñez NG, et al. Salivary gland adenocarcinomas: a clinicopathologic analysis of three distinct types. Semin Diagn Pathol 1987:4:117-35.

5 Lewis JE, McKinney BC, Weiland LH, et al. Salivary duct carcinoma. Clinicopathologic and immunohistochemical review of 26 cases. Cancer 1996;77:223-30.

6 Barnes L, Rao U, Krause J, et al. Salivary duct carcinoma. Part I. A clinocopathologic evaluation and DNA image analysis of 13 cases with review of the literature. Oral Surg Oral Med Oral Pathol 1994;78:64-73.

7 Barnes L, Rao U, Contis L, et al. Salivary duct carcinoma. Part II. Immunohistochemical evaluation of 13 cases for estrogen and progesterone receptors, cathepsin D and c-erbB-2 protein. Oral Surg Oral Med Oral Pathol 1994:78:74-80.

8 Felix A, El-Naggar AK, Press MF, et al. Prognostic significance of biomarkers (c-erbB-2, p53, proliferating cell nuclear antigen and DNA content) in salivary duct carcinoma. Hum Pathol 1996;27:561-6.

9 Kamino N. Coexpression of p53 and c-erbB-2 proteins is associated with histological type, tumor stage, and cell proliferation in malignant salivary gland tumors. Virchows Arch 1996;428:75-83.

10 Martinez-Barba E, Cortes-Guardiola JA, Minguela-Puras A, et al. Salivary duct carcinoma: clinicopathologic and immunohistochemical studies. J Craniomaxillofac Surg 1997;25:328-34.

11 Madrigal B, Garcia J, De Vicente JC. Salivary duct carcinoma: an unusual case of long-term evolution. Oral Surg Oral Med Oral Pathol 1999;88:597-602.

12 Lopes MA, Alves FA, Levy BA, et al. Intraoral salivary duct carcinoma: case report with immunohistochemical observations. Oral Surg Oral Med Oral Pathol 2001;91:689-92.

13 De Araújo VC, Loducca SVL, Sobral APV, et al. Salivary duct carcinomacytokeratin 14 as a marker of in-situ intraductal growth. Histopathology 2002:41:244-9.

14 Kusume T, Tsuda H, Kawabata M, et al. The p16-cyclin D1/cak-4-pRb pathway and clinical outcome in epithelial ovarian cancer. Clin Cancer Res 1999;5:4152-7.

15 Ralhan R, Mathew R, Arora $S$, et al. Frequent alterations in the expression of tumor suppressor genes $\mathrm{pl}^{\mathrm{INK} 4 \mathrm{a}}$ and $\mathrm{pRb}$ in esophageal squamous cell carcinoma in the Indian population. J Cancer Res Clin Oncol 2000;126:655-60.

16 Shintani S, Mihara M, Nakahara Y, et al. Infrequent alterations of RB pathway (Rb-p16 $6^{\mathrm{NK} 4 \mathrm{~A}}$-cyclin D1) in adenoid cystic carcinoma of salivary glands. Anticancer Res 2000;20:2169-76.

17 Hellquist HB, Karlsson MG, Nilsson C. Salivary duct carcinoma-a highly aggressive salivary gland tumour with overexpression of c-erbB-2. J Pathol 1994; 172:35-44.

18 Mineta H, Miura K, Takebayashi S, et al. Cyclin Dl overexpression correlates with poor prognosis in patients with tongue squamous cell carcinoma. Oral Oncol 2000;36:194-8.

19 Schoelch ML, Regezi JA, Dekker NP, et al. Cell cycle proteins and the development of oral squamous cell carcinoma. Oral Oncol 1999;35:333-42.

20 Koontongkaew S, Chareonkitkajorn L, Chanvitan A, et al. Alterations of p53, $\mathrm{pRb}$, cyclin Dl and cdk4 in human oral and pharyngeal squamous cell carcinomas. Oral Oncol 2000;36:334-9.

21 Si X, Liu Z. Expression and significance of cell cycle-related proteins cyclin D1, cdk 4, p27, E2F-1 and Ets-1 in chondrosarcoma of the jaws. Oral Oncol $2001 ; 37: 431-6$.
22 Mathew R, Arora S, Khanna R, et al. Alterations in cyclin D1 expression in esophageal squamous cell carcinoma in the Indian population. J Cancer Res Clin Oncol 2001;127:251-7.

23 Nevins JR. The Rb/E2F pathway and cancer. Hum Mol Genet 2001;10:699-703.

24 Bartkova J, Thullberg M, Slezak P, et al. Aberrant expression of G1-phase cell cycle regulators in flat and exophytic adenomas of the human colon. Gastroenterology 2001;120:1680-8.

25 Chen PL, Scully P, Schew J-Y, et al. Phosphorylation of the retinoblastoma gene product is modulated during the cell cycle and cellular differentiation. Cell 1989;58:1193-8.

26 Hermeking $\mathbf{H}$, Rago $C$, Schuhmacher $M$, et al. Identification of cdk-4 as a target of c-Myc. Proc Natl Acad Sci U S A 2000;29:2229-34.

27 He TC, Sparks AB, Rago C, et al. Identification of c-Myc as a target of the APC pathway. Science 1998;281:1509-12.

28 Nielsen GP, Stemmer-Rachamimov AO, Shaw J, et al. Immunohistochemical survey of p $16^{\text {ink } 4 \mathrm{~A}}$ expression in normal human adult and infant tissues. Lab Invest 1999;79:1137-43.

29 Medema RH, Herrera RE, Lam F, et al. Growth suppression by $166^{\text {ink4 }}$ requires functional retinoblastoma protein. Proc Natl Acad Sci U S A 1995;92:6289-93.

30 Cerilli LA, Swartzbaugh JR, Saadut R, et al. Analysis of chromosome 9p21 deletion and pl 6 gene mutation in salivary gland carcinomas. Hum Pathol 1999:30:1242-6.

31 Bringold F, Serrano M. Tumor suppressors and oncogenes in cellular senescence. Exp Gerontol 2000;35:317-29.

32 Adams PD. Regulation of the retinoblastoma tumor suppressor protein by cyclin/cdks. Biochim Biophys Acta 2001;1471:M123-33.

33 Lundberg AS, Weinberg RA. Control of the cell cycle and apoptosis. Eur J Cancer 1999;35:531-9.

34 Kubbutat MHG, Jones SN, Vousden K. Regulation of p53 stability by Mdm2. Nature 1997:387:299-303.

35 Yamamoto T, Ikawa S, Akiyama T, et al. Similarity of protein encoded by the human c-erbB-2 gene to epidermal growth factor receptor. Nature $1986 ; 319: 230-4$

36 Lewis JE, Olsen KD, Sebo TJ. Carcinoma ex pleomorphic adenoma: pathologic analysis of 73 cases. Hum Pathol 2001;32:596-604.

37 Sugano S, Mukai K, Tsuda H, et al. Immunohistochemical study of c-erbB-2 oncoprotein overexpression in human major salivary gland carcinoma: an indicator of aggressiveness. Laryongoscope 1992;102:923-7.

$38 \mathrm{Kim}$ YT, Kim JW, Lee JW. c-erbB-2 oncoprotein assay in ovarian carcinoma and its clinical correlation with prognostic factors. Cancer Lett 1998;132:91-7.

39 Slamon DJ, Godolphin W, Jones LA, et al. Studies of the HER-2/neu protooncogene in human breast and ovarian cancer. Science 1989;244:707-12.

40 Cho K-J, Lee S-S, Lee Y-S. Proliferating cell nuclear antigen and c-erbb-2 oncoprotein expression in adenoid cystic carcinomas of the salivary glands. Head Neck 1999;21:414-19.

41 Press MF, Pick MC, Hung G, et al. Amplification and overexpression of HER$2 /$ neu in carcinomas of the salivary gland: correlation with poor prognosis. Cancer Res 1994;54:5675-82

42 Eccles SA. Cell biology of lymphatic metastasis. The potential role of c-erbB oncogene signalling. Rec Results Cancer Res 2000;157:41-54.

43 Tan M, Yao J, Yu D. Overexpression of the c-erbB-2 gene enhanced intrinsic metastasis potential in human breast cancer cells without increasing their transformation abilities. Cancer Res 1997; 57:1199-205.

44 O-charoenrat PO, Rhys-Evans PH, Archer DJ, et al. C-erbB receptors in squamous cell carcinomas of the head and neck: clinical significance and correlation with metalloproteinases and vascular endothelial growth factors. Oral Oncol 2002;38:73-80

45 De Potter C, Quatacker J. The p185 erbB2 is localized on cell organelles involved in cell motility. Clin Exp Metastasis 1993;11:453-61. 